\title{
Involving Young People in Polish and Lithuanian Social Enterprises by Fostering Entrepreneurial Skills and Abilities as Entrepreneurial Opportunity at University
}

\author{
Jolita Greblikaite, Włodzimierz Sroka, Neringa Gerulaitiene
}

\begin{abstract}
A B S T R A C T
Objective: The paper aims to analyse theoretically and empirically the development of social entrepreneurship in Poland and Lithuania, emphasizing the development of appropriate skills and abilities gained at university as entrepreneurial opportunity.

Research Design \& Methods: The research undertaken for the purposes of the paper is based on a literature review and empirical research partly devoted to a situational analysis of social entrepreneurship in Poland, as well as a pilot survey of target groups pertaining to the entrepreneurial skills and abilities as entrepreneurial opportunity of Lithuanian and Polish students as potential social entrepreneurs.
\end{abstract}

Findings: The main research findings imply that despite the existence of entrepreneurial opportunity as education at university, social entrepreneurship is increasingly important in Poland. Overall support is needed for the creation of social enterprises and attracting young people to them. Empirical research based on Lithuanian and Polish students' perception of acquiring entrepreneurial skills and abilities at university can be entrepreneurial opportunity for social entrepreneurship.

Implications \& Recommendations: Implementing further research in the field, as empirical this research was just a pilot one. Research can be developed by taking into account more respondents in both countries.

Contribution \& Value Added: The study provides empirical evidence entrepreneurial skills and abilities gained/developed at university are a possible entrepreneurial opportunity for exploiting and creating social enterprises.

\section{Article type: research paper}

Keywords: social entrepreneurship; entrepreneurial opportunities; entrepre-

Keywords: neurial skills and abilities; young entrepreneurs

JEL codes: M30

Received: 5 May 2016

Revised: 8 August 2016

Accepted: 12 August 2016

\section{Suggested citation:}

Greblikaite, J., Sroka, W., \& Gerulaitiene, N. (2016). Involving Young People in Polish and Lithuanian Social Enterprises by Fostering Entrepreneurial Skills and Abilities as Entrepreneurial Opportunity at University. Entrepreneurial Business and Economics Review, 4(3), 131-152, DOI: http://dx.doi.org/10.15678/EBER.2016.040310 


\section{INTRODUCTION}

The European Union (EU) is subject to a rather complicated situation in terms of employment of young people. This relates to several European countries, especially Greece and Spain; however, in both Lithuania and Poland, a somewhat difficult situation on the labour market exists as well. The demographics of unemployment show that a significant proportion of the unemployed are youths. The EU suggests and promotes numerous instruments aimed at reducing the level of unemployment amongst young people. One of these instruments is the development of entrepreneurial skills and abilities among young people and subsequently attracting those young people to business in order to bring the ideas they have to fruition. Numerous examples of 'good practice' might be found in other EU countries - therefore it is of vital importance to use those examples appropriately in EU countries.

The analysis is focused on the situation in Poland and Lithuania in terms of solving economic and social problems through the involvement of young people in entrepreneurship; especially social enterprises. Prior research in the field covers many spheres and viewpoints researching social entrepreneurship. Thomson (2002), Drayton (2002), Korosec and Berman (2006), Peredo and McLean (2008) defined characteristics of social entrepreneurs. Mair and Marti (2006) analysed different combinations of resources implementing social activity, Hausner (2008) was analysing the role of social entrepreneurship, Zahra, Gedajlovic, Neubam and Shulman (2009) analysed the concept of social entrepreneurship, including entrepreneurial opportunities, Doherty, Haugh and Lyon (2014) analysed social value creation peculiarities. In the context of this paper, other analysed research works might be grouped as analysing some special issue of entrepreneurship as entrepreneurial opportunities. Casson (1982), Shane and Venkataraman (2000), Shane (2003), Ardichvili, Cardozo and Sourav (2003), Davidsson and Honig (2003), Audretsch and Acs (2003), Dutta and Crossan (2005), Shepherd and DeTienne (2005), Dimov (2007), Aldrich and Martinez (2007), Plummer, Haynie and Godesiabois (2007), Davidson (2008), Smith, Matthews and Schenkel (2009), Ucbasaran, Westhead and Wright (2009), De Jong (2009), Short, Ketchen, Shook and Ireland (2010), Fuentes et al. (2010), Soderqvist (2011), Dahlqvist, Wiklund (2012). Jesensky (2013) analysed different aspects of entrepreneurial opportunities possibly actual in social enterprises creation. Despite analysed research, the research fulfilled in this article focuses on less analysed field as authors trying to develop social entrepreneurship creation possibilities through accepting entrepreneurial skills and abilities as entrepreneurial opportunity especially for young people involvement in social enterprises creation.

The scientific problem of the article pertains to the question of how to improve the environment for entrepreneurial development in Poland and Lithuania, and attract young people to business in order to exploit entrepreneurial opportunities for creating social enterprises. The subject of the research is social entrepreneurship, based on the support of social entrepreneurship through the education and teaching of appropriate skills and abilities at university as entrepreneurial opportunity. The research aim is to analyse theoretically and empirically the development of social entrepreneurship in Poland and Lithuania, emphasizing the development of appropriate skills and abilities gained at university as entrepreneurial opportunity. The research tasks are: 
1. To analyse entrepreneurial opportunities of social entrepreneurship development focusing on entrepreneurial skills and abilities;

2. To evaluate the potential and situation of social entrepreneurship development, especially in the case of social enterprises in Poland;

3. To present comparative analysis of pilot empirical research into entrepreneurial skills and abilities gained at university as entrepreneurial opportunity in Lithuania and Poland;

4. To provide recommendations and suggestions on how to engage young people in entrepreneurship, especially social enterprises, integrating the education process in the overall support system for entrepreneurship in Poland and Lithuania.

The first part of the article is devoted to presenting the essential issues related to the analysed object from theoretical viewpoint: the concept of social entrepreneurship and its dimensions are presented; entrepreneurial skills and abilities are analysed as entrepreneurial opportunity for deeper analysis of social entrepreneurship involving young people. Second part of the article presents the methodological assumptions applied to empirical research. Third part presents the results and discussion of situation analysis in Poland and pilot empirical research results about fostering and developing entrepreneurial skills and abilities at university for developing social entrepreneurship in Lithuania and Poland. In the end, some conclusions and recommendations are provided.

\section{LITERATURE REVIEW}

Entrepreneurship itself is analysed in a vast number of different scientific publications. Different angles of analysis are chosen and various aspects have been researched. In the framework of the scientific problem raised in this article, it is most important to review and analyse the scientific works on the concept of social entrepreneurship and entrepreneurial opportunities and the exploitation thereof, paying attention to the place of entrepreneurial skills and abilities in this context.

\section{Concept of Social Entrepreneurship}

In recent decades, entrepreneurship research has focused on social value, influence on and interaction with society and has been preconditioned to the foundations of social entrepreneurship and analysis. Zahra et al. (2009), in summarising various assumptions on social entrepreneurship, state that social entrepreneurship encompasses the activities and processes undertaken to discover, define, and exploit opportunities in order to enhance social wealth by creating new ventures or managing existing organisations in an innovative manner. A social entrepreneur simply might be someone who organises and/or operates a venture or corporation, which fulfils social goals (Peredo \& McLean, 2006).

The role of communities is especially stressed in the context of social entrepreneurship. Korosec and Berman (2006) define social entrepreneurs as individuals or private organisations that take the initiative to identify and address important social problems in their communities. According to Thompson (2002), social entrepreneurs are also said to possess the qualities and behaviours generally associated with business entrepreneurs, 
but they operate in communities and are more concerned with caring and helping than with making money. The approach of social entrepreneurship unites business and communities, and the essence of it relies upon the coherence of business and society. The term 'social enterprise' links two main attributes: 'entrepreneurship' and 'community'. The first means that it relates to the organisation, which conducts business that is associated with the economic risk and verification of the effects of this economic activity. In turn, the second attribute, i.e. 'community', indicates on the one hand the basic resources that are used by the company (based on social capital, shaped within a particular community), and, on the other hand, its mission (the activity of the company is focused on social integration within the local community and its main aim is to prevent social exclusion through professional elicitation and activity) (Hausner, 2008, p. 10).

The other important aspect in any discussion of social entrepreneurship relies upon the allocation of resources, which leads to the creation of new enterprises. Mair and Marti (2006) perceive social entrepreneurship as a process of creating value by combining resources in new ways. Secondly, these resource combinations are intended primarily to explore and exploit opportunities to create social value by stimulating social change or meeting social needs. Third, researchers viewing social entrepreneurship as a process emphasise that it involves offering services and products, but can also refer to the creation of new organisations. The authors argue that the profit motive of entrepreneurship can be a partial motive for social entrepreneurship as it might be presumed that the motives for social entrepreneurship can be, for example, personal satisfaction or fulfilment. It is also said that entrepreneurship in the business sector also has a social aspect. Drayton (2002) emphasises the strong ethical fibre of the entrepreneur. Societal focus appears strongly related to the character of entrepreneurs, as such; people are frequently very active in society because of the nature of their behaviour and character features, as well as the skills and abilities, which the social entrepreneur possesses.

The dual mission - financial and social sustainability - of social enterprises shapes the processes of opportunity recognition and exploitation in that value capture is tied, either directly or indirectly, to social value creation (Doherty et al., 2014). Such a hybrid nature of social enterprises increases the complexity of management processes. In these enterprises, the activities of different partnerships are involved as well (Thompson, 2002; Doherty et al., 2014).

Two distinct types of problems are frequently solved by social enterprises. The first one is financing problems, which are related to the social mission of such enterprises and without any defined profit because of their activity. Social enterprises lack support from traditional financing institutions. Therefore, the demand for special financing instruments remains in this sector.

The other group of problems inherent in social enterprises is related to human resource management. Social enterprises suffer shortages in terms of the skilled labour force, sometimes due to financial problems, sometimes perhaps related to the specific activity of social enterprises. Attracting volunteers and minor groups is a specific issue with different managerial aspects. Work with minor groups' demands managerial capabilities and the skills effectively solve various situations and concerns arising from casual activity. Voluntary work has its own issues based on, for example, unpredictable resources in the appropriate moment, the motivation of the work force, the amount of 
free time allocated to different tasks, and so on. However, it should be taken into consideration that volunteers in most cases are young people, especially students. That could become a precondition for the involvement of young people in creating social enterprises. They are often full of entrepreneurial ideas and need to see entrepreneurial opportunities and exploit them.

\section{Entrepreneurial Opportunities for Social Enterprise Creation: Focus on Entrepreneurial Skills and Abilities Gained at University}

Without an opportunity, there is no entrepreneurship (Jesensky, 2013). Shane and Venkataraman (2000) state that to have entrepreneurship, we must first have entrepreneurial opportunities. A potential entrepreneur can be creative and hardworking, but without an opportunity, entrepreneurial activities cannot take place (Short et al., 2010). According to this, social entrepreneurship without entrepreneurial opportunity cannot take place.

Entrepreneurship involves the nexus of entrepreneurial opportunities and enterprising individuals. This nexus indicates that opportunities are an important part of the entrepreneurial process (Shane, 2003). Opportunity is a central concept within the field of social entrepreneurship. Understanding entrepreneurial opportunities is important because the characteristics of an opportunity influence the entrepreneurial process (Shane, 2003).

Following Casson (1982), Shane and Venkataraman (2000), Eckhardt and Shane (2003) defined entrepreneurial opportunities as situations in which new goods, services, raw materials, markets and organising methods can be introduced through the formation of new means, ends, or means-ends relationships.

An entrepreneurial opportunity is more accurately described as an opportunity to engage in entrepreneurial action, in which entrepreneurial denotes a sub-class of some broader category of human action, which is motivated by profit. The adjective 'entrepreneurial' is used to qualify the manner by which this profit is sought - i.e. through the introduction of new goods or services (Companys \& McMullen, 2007).

Entrepreneurial opportunities can be represented as a stream of continuously developed ideas, driven and shaped by one's social interaction, creative insights, and action at each stage of entrepreneurship (Dimov, 2007).

Entrepreneurial opportunities consist of a set of ideas, beliefs and actions that enable the creation of future goods and services in the absence of current markets for them (Shane \& Venkataraman, 2000). Entrepreneurial opportunity consists of new idea/s or invention/s that may or may not lead to the achievement of one or more economic ends that become possible through ideas or inventions; beliefs pertaining to factors favourable to the achievement of those possible valuable ends; and actions that generate and implement those ends through specific economic artefacts (the artefacts may be goods such as products and services and/or entitles such as firms and markets, and/or institutions such as standards and norms) (Audretsch \& Acs, 2003).

Shane and Venkataraman (2000) have argued that entrepreneurial opportunities are "objective phenomena", existing in time and space even though they may not be known to all people at all times (Companys \& McMullen, 2007). Holcombe (2003) opined that the information needed to seize some entrepreneurial opportunities comes from sources available in principle to everyone, although recognising that information that a person 
acquires constitutes an entrepreneurial opportunity may also require some specific knowledge of time and place. The duration of any opportunity depends on a variety of factors - such as patent rights, information diffusion, or the inability of others to imitate (Shane \& Venkataraman, 2000).

Social enterprises have to pay attention to three valuable ways of categorising opportunities: by the locus of changes that generate the opportunity; by the source of the opportunities themselves; and by the initiator of the change (Eckhardt \& Shane, 2003).

Schumpteter (1934) suggested in brief detail five different loci of these changes: those that stem from the creation of new products or services, those that stem from the discovery of new geographical markets, those that emerge from the creation or discovery of new raw materials, those that emerge from new methods of production, and those that are generated from new ways of organising.

Prior research suggests four important ways of categorising opportunities by sources. The first involves considering differences between opportunities that result from asymmetries in existing information between market participants and opportunities that result from exogenous shocks of new information. The second comparison lies between supply- and demand-side opportunities. The third differentiates between productivity-enhancing and rent-seeking opportunities, and the fourth lies in identifying the catalysts of change that generate the opportunities.

The final dimension by which opportunities have been classified is by the actor that initiates the change. Different types of entities initiate the changes that result in entrepreneurial opportunities, and the type of initiator is likely to influence the process of discovery as well as the value and duration of the opportunities. Among the different types of actors that researchers have identified are non-commercial entities, such as governments or universities; existing commercial entities in an industry, such as incumbents and their suppliers and customers; and new commercial entities in an industry such as independent entrepreneurs and diversifying entrants (Eckhard \& Shane, 2003).

To sum up, an entrepreneurial opportunity could arise from the locus of the change, the source of the opportunities themselves and the initiator of the change. As claimed by Fuentes, Arroyo and Perez (2010), if opportunities exist, why are they not exploited? The answer is clear: the process of identifying and subsequently exploiting opportunities is complex and involves some "discovery costs" (Casson \& Wadeson, 2007).

Entrepreneurial opportunity exploitation is part of the entrepreneurial process. According to Davidson (2008), the exploitation process is defined in terms of entrepreneurial actions or behaviours, such as resource acquisition and coordination and market making, networking, and business planning, which are aimed at the fulfilment of a venture concept. Exploitation is associated with the full-scale operation, which requires the full commitment of the new venture's resources in building efficient production and business systems (Choi \& Shepherd, 2004).

Entrepreneurial opportunity exploitation is explained by the ability to execute a new venture, which is driven by motivation, the ability to mobilise resources and control the new organisation (Aldrich \& Martinez, 2007; Dahlqvist \& Wiklund, 2012). Social enterprises could be one of the results of entrepreneurial opportunity exploitation.

Zahra, Korri and Yu (2005) emphasise that only during the process of exploiting an opportunity is the opportunity actually created (Soderqvist, 2011). Opportunities are 
usually exploited only when human beings decide to act (De Jong, 2009). As claimed by Zahra et al. (2005), the exploitation of opportunities always involves uncertainty and risk (Soderqvist, 2011). Opportunity exploitation also correlates with individuals' attitude and perceived subjective norms towards the opportunity, and perceived behavioural control in order to successful implementation of opportunity (De Jong, 2009). Moreover, successful opportunity exploitation depends on opportunity characteristics, the environment, and the entrepreneur's individual motives (Plummer et al., 2007).

An entrepreneur starting a venture is strongly attached to the opportunity and tends to avoid any exit from the venture process. Rather, when an opportunity seems unviable (perhaps because a competitor has moved faster on it) entrepreneurs are likely to modify it or move onto a new, but related, opportunity (Choi, Levesque \& Shepherd, 2008).

Shane and Venkataraman (2000) state that the exploitation decision is influenced by both the nature of the opportunity and by individual differences. The former refers to aspects such as the expected return provided by the opportunity, the costs involved, its lifespan as well as the level of demand. The later implies that there are also differences between people regarding how much risk they are willing to take.

As Ardichvili et al. (2003) argue, the most important factors that influence the recognition and exploitation of opportunities are the entrepreneur's alertness to such opportunities, asymmetrical information and prior knowledge, social networks, the personality traits of the entrepreneur and the nature of the opportunity itself. Roure, González, Nieto, García and Solís (2007) find that the number of new firms depends on the externalities of knowledge of a region and the entrepreneur's possession of abilities and knowledge.

There are three main determinants influencing entrepreneurial opportunity exploitation: prior knowledge, personal traits and social networks (Shane, 2003). The role of prior knowledge and learning in the identification and exploitation of entrepreneurial opportunities has received consistent attention in the literature (Dutta \& Crossan, 2005; Dimov, 2007; Smith et al., 2009; Ucbasaran et al., 2009).

Prior knowledge comes from various sources: education, personal history, and work experience, advice from experts, imitation and copying (Davidsson \& Honig, 2003; Shepherd \& DeTienne, 2005). Different external sources of prior knowledge can help social enterprises recognise and exploit different types of opportunities.

Choi and Shepherd (2004), in analysing the major dimensions of prior knowledge, suggest that entrepreneurs are more likely to exploit opportunities when they have more knowledge of customer demands for new products, or they have more fully developed the necessary technologies or greater managerial capability (Fuentes et al., 2010). According to von Hippel (1994), people tend to notice information that is related to information they already know. Shane (2000) postulated that entrepreneurs would discover opportunities because prior knowledge triggers recognition of the value of the new information. Drawing on the Austrian economics argument that entrepreneurship exists because of information asymmetry between different actors (Hayek, 1945), Shane maintains that any given entrepreneur will discover only those opportunities related to his or her prior knowledge. To sum up, prior knowledge has an important role in the exploitation of entrepreneurial opportunities. It triggers the creation of social enterprises. Social entrepreneurs are more successful if they have sufficient prior knowledge. It can be 
presumed that entrepreneurial skills and abilities might be entrepreneurial opportunity as well as raise itself entrepreneurial opportunities.

In summary, without an entrepreneurial opportunity, there is no social entrepreneurship, and only during the process of exploiting an opportunity is that the opportunity is actually created. An entrepreneurial opportunity could arise from the locus of the change, the source of the opportunities themselves and the initiator of the change. The main determinants influencing entrepreneurial opportunity exploitation are prior knowledge, personal traits and social networks. All of these determinants have an impact on the success of a social enterprise. Prior knowledge enables young social entrepreneurs to exploit entrepreneurial opportunities. The source of this prior knowledge could successfully augment education gained at university, providing appropriate entrepreneurial skills and abilities for young social entrepreneurs.

The contribution to the research area of social entrepreneurship development through entrepreneurial skills and abilities development at university as entrepreneurial opportunity is not researched enough and the linking these two-research objects presumably might lead to improvement of social entrepreneurship implementation. Social entrepreneurship research especially in Poland and Lithuania is lacking, as the object is rather new for analysis worldwide and especially in these countries. Especially practical implementation questions are discussed quite fragmentally and lack deeper analysis. Scientific discussion on social entrepreneurship mostly takes place on a conceptual level: what it is, what functions are fulfilled by phenomena, what benefit is created by implementing it. This paper seeks to make a contribution to the theory combining theoretical and empirical research to entrepreneurial skills and abilities as entrepreneurial opportunities preconditioning social enterprises creation.

\section{MATERIAL AND METHODS}

The empirical part of the article is based on situation analysis, document analysis and pilot target survey analysis. There are two main aims of our study: 1 ) the empirical research aim is to evaluate the potential of social entrepreneurship development, with an emphasis on Poland, and 2) to present the analysis of empirical research on entrepreneurial skills and abilities gained at university (entrepreneurial opportunity) in Lithuania and Poland. Both the situation and document analysis are designed to analyse the potential and development of social entrepreneurship in Poland, focusing attention on social enterprises and youth involvement in this activity. The analysis is focused on the economic, political, legal and social environments. Emphasis is placed on the education system as an entrepreneurial opportunity for social entrepreneurs. Qualitative research as empirical research method is selected as mostly appropriate.

The pilot target survey analysis is fulfilled in target groups of students (Kaunas University of Technology, Master students, Study programme - International Business, $n=20$, year 2013, 2014; called Group A in the Results section). Target group B is students of Polish Dabrowa Gornicza University, studying International communication $(n=22$, year 2016). This target survey is kept as pilotage one (authors wanted to analyse the approach of young students from two neighbouring countries to the issue of entrepreneurship). The results obtained could be then further developed on larger samples. Therefore, authors decided to choose two relatively small groups of students consisting 
of ca. 20 people especially for confirmation of necessity of such research and further improvement of questionnaire as an instrument for research as well as such sample selection was based on such assumptions as:

- Lithuanian students' group was listener of special Entrepreneurship course;

- Polish students' group was non-listeners of any special course of Entrepreneurship.

Such differences allow comparing in general very different groups and making assumptions based on similarities and distinctions in both target groups as empirical research object. It should be stressed that this research is unique in its construct and fulfilled in Lithuania and Poland without existing similar research results. The research is not focusing on the education of entrepreneurial skills and abilities, its techniques or methods. The research is focuses on entrepreneurial opportunity creation through teaching social entrepreneurship at universities, colleges or even schools for inspiring young people for becoming social entrepreneurs.

Lithuanian Target group A students were participants in the teaching course 'Entrepreneurship and good practice examples of SMEs'. The questions in the survey were similar for all target groups:

1. Have you ever attended a course on entrepreneurship? If yes, name the course.

2. What is your opinion about the background of entrepreneurs: are entrepreneurs born or can they be made?

3. Which features of character do you think are most important in terms of entrepreneurial activity? How might these features be developed during tertiary study?

4. What entrepreneurial skills and abilities might be developed during tertiary study?

5. What conditions or/and measures could strengthen entrepreneurial potential at university?

6. To what extent is the analysis of best practice or good practice important to the development of entrepreneurial spirit?

7. What new methods or measures could be appropriate for the development of entrepreneurial skills and abilities at university? Should some special attention be paid to an understanding of social entrepreneurship?

8. How important is the complex learning and education process of entrepreneurial skills and abilities when it is undertaken at the primary, secondary and tertiary stages of education respectively?

9. What is the most important factor in successful entrepreneurial education and the implementation of entrepreneurial ideas in practice?

10. Social entrepreneurship, social entrepreneurs, social enterprises, and social innovation are priorities in the developing economy in Lithuania and throughout the EU. Have you heard of them and would you be interested in finding out more about the management of social enterprises during your studies?

The interpretation of results is presented in the next section. The results are also compared to those of another target survey undertaken at X University in EU where the respondents were representatives of international students $(n=11$, year 2015; target group called Group C) participating in the 'European civilisation history and culture' course and studying the Bachelor programme of Business Management. The selection of the group was based on their internationalization, seeking to make an advanced compar- 
ison of different study experiences. It must be stressed that this Group C does not represent any particular country results (not Poland nor Lithuania). In analysing the results of this focus group (international students at X University), it became apparent that just one respondent was involved in the entrepreneurship course in reality, meaning that this target group is rather different from the previous one Target group $A$. The questions were the same as those mentioned above and used to $\operatorname{target}$ group $A, B$, and C.

\section{RESULTS}

\section{Social Entrepreneurship in Poland: Situation Analysis}

\section{Social Entrepreneurship in Poland: a Historical Approach}

Nowadays in Poland, there is a depth of discussion on social entrepreneurship taking place. Among numerous publications, several studies are worth mentioning. A study by Hausner (2008) provides a comprehensive scientific analysis on the conditions for the establishment and activities of social enterprises in Poland (the genesis and specificity of social enterprises, their institutional fixation and the related regulations, as well as Polish and international good practices concerning the establishment and activities of social enterprises). Both areas of activity of enterprises and their financial structure have been described in detail. In turn, Ciepielewska-Kowalik $(2013,2015)$ raised different topics in her studies, which were mostly concentrated on trends and challenges for social enterprises in Poland, models of social enterprises, and the institutional and historical context of social enterprises in the country. Leś (2004) as well as Leś and Ciepielewska-Kowalik (2014) focuses her deliberations on cooperatives, as well as trends, challenges and obstacles in the social economy sector. Finally, Kurleto (2013) analyses the possibility of the application of American solutions in the sphere of social entrepreneurship in Poland.

Generally, it is necessary to state that social enterprise organisations in Poland have strong and complicated traditions, dating back to long before the Second World War (Ciepielewska-Kowalik, Pieliński, Starnawska \& Szymańska, 2015; Herbst, 2008). In some cases (e.g. cooperatives), they even appeared before the beginning of the nineteenth century, since when they have undergone turbulent periods of change. Three basic historical periods of the development thereof may be distinguished (Ciepielewska-Kowalik et al., 2015):

- the period prior to the Second World War (the first period),

- the period during Communist rule, i.e. between 1945 and 1989 (the second period),

- the transition period, after 1989 (the third period).

There were significant differences between the particular sub-periods regarding the perception of social enterprises as well as actions taken. There were also some similarities, especially between the first and second period. The real re-interest in the concept of the social economy as an instrument of social policy increased substantially during the third period, and especially after accession to the EU (Kurleto, 2013; Greblikaite, Sroka \& Grants, 2015).

Despite these facts, it is necessary to mention that no comprehensive research has been conducted in Poland to measure the nationwide development of social entrepreneurship. The available analyses relate to selected aspects of the phenomenon or a par- 
ticular region, case studies and reports on programmes oriented towards the development of social entrepreneurship (Kusa, 2012), and despite growing interest in social entrepreneurship among scholars over the last two decades, the literature on social entrepreneurship still remains diffuse and fragmented (Austen-Tynda, 2008).

\section{Social Enterprises in Poland: Selected Data and Key Factors of Development}

There is no official data on the number of social enterprises in Poland. One estimates that in 2012 there were around 5200 entities in Poland, which could be classified as social enterprises by applying the EU Operational Programmes, employing around 70000 people. This represents around $0.3 \%$ of all registered and active enterprises (including sole trader ships) and around $0.4 \%$ of the total employment in the economy (European Commission, 2014). Social enterprises play an important role in work integration activities for groups endangered by social exclusion, which specifically affects the long-term unemployed, homeless, addicts and the isolated (Kożuch \& Žukovskis, 2014). They also provide a wide variety of services of general economic interest such as education, social care services, as well as other specialised services.

Given the data presented, the Polish Government promotes social entrepreneurship. Therefore, a National Programme for Social Economy Development (KPRES) was implemented and now has the status of an official government document. It is the first comprehensive legal act that fully recognises the social economy in Poland, and determines the key directions of public support for the social economy. This act defines the activities, which should be undertaken by the Polish public authorities to strengthen the sector of the social economy. As a result, the position of the social economy has been given new developmental opportunities. According to the KPRES Programme, organisations of the social economy are to have several major goals, such as to integrate the socially excluded (or those threatened by social exclusion), to create workplaces, to provide welfare services, and to support local development. It should also contribute significantly to employment growth, social coherence, and the development of social capital.

The growth of social enterprises in Poland does not necessarily mean that there is no need to support them. On the contrary, there are several forms of support for social enterprises, which were indicated by the representatives of this sector. The most important include direct subsidies, as well as preferential loans and credits. On the other hand, the European Commission (2014) claims that there are no specialist investors or intermediaries investing in or offering financial products to social enterprises in Poland. In theory, social enterprises may borrow on the same terms as mainstream enterprises, albeit in practice, demand for financing appears very limited and access is limited. Grant funding is available to social economy entities from structural funds programmes.

There are also a limited number of financial instruments specifically aimed at social economy entities including social enterprises. They include two commercial loan funds:

- The Polish-American Community Assistance Fund (PAFPIO) financing nongovernmental organisations,

- TISE financing all social economy entities.

In addition, one can find examples of small local initiatives such as microloan and guarantee funds and social venture capital funds that are piloted from time to time. Another example could be certain regional funds, such as the Fund for Social Economy in 
Małopolska (Małopolski Fundusz Ekonomii Społecznej), which was established in 2009 by private and public entities and specialises in the provision of credit guarantees for social enterprises. To date it has provided 103 guarantees and small loans totalling 1.2 million EUR, contributing to the creation of 32 social cooperatives and 35 microenterprises (European Commission, 2014).

When speaking on other forms of support of social entrepreneurship in Poland, one may mention access to free information and advice services, a wider promotional range, as well as the use of guarantee funds and credit guarantee funds. These, however, areregarded as the least important form of support (Hausner, 2008). Fortunately, there are some positives in this regard. For example, as was stated by Starnawska (2011), the promotion of social enterprise and social entrepreneurship has been undertaken by several initiatives. One of them is a national competition for Social Enterprise of the Year, introduced in 2011 by the Foundation of Social and Economic Initiatives (FISE). Another such initiative is the world-renowned program by Ashoka Foundation that has been identifying its fellows in Poland since 1995. An additional initiative, which promotes social enterprise, comes from other international programmes, such as NESsT and the JPMorgan Chase Foundation, which have announced the first awards for the best business plan from a social enterprise in 2014. Generally, it is necessary to state that although these initiatives and programs are varied in their scope and aims, they contribute to the promotion of social enterprise and the development of social entrepreneurship in Poland.

\section{Barriers to the Growth of Social Entrepreneurship in Poland}

Despite the dynamic growth of social enterprises, there are a number of barriers to their development, which include the accumulation of negative, social and economic features in rural and underdeveloped areas, lack of trust in the initiatives undertaken by social enterprises, the low level of activity of local communities, lack of social trust in partnership-building skills and collaboration in achieving common objectives and lack of cooperation between social enterprises (Greblikaite et al., 2015). A large group of representatives of social enterprises surveyed were also of the opinion that it is easier to find an employee or customer by concealing the social nature of the business.

A very important factor in weakening the position of the social enterprises operating in the market is to treat them under the law as non-governmental sector entities. The result of this treatment is the existence of a kind of social enterprise discrimination when compared to commercial entities. This type of discrimination is particularly evident in access to preferential training and raising funds for investment. Furthermore, these companies are not recognised by law as non-governmental organisations, and cannot obtain financial funds in a similar manner.

Despite the problems mentioned, it is possible to surmise that the development of social entrepreneurship should be expected to continue, driven by both demand and the capacity of social entrepreneurship to meet this demand. Despite systematic progress in all areas of life, social needs, exclusion or stratification continue apace. Societies have limited public resources to tackle social problems. On the other hand, increasing numbers of individuals have the capabilities (including time and skills) to join the process of finding solutions to social problems. The standards of enterprise knowledge and skills are rising and can be taken advantage of to solve problems of a social nature (Kusa, 2012). 


\section{The Role of the Educational System in Poland}

The education system plays an important role in shaping and developing social entrepreneurship in Poland. It is said that the only effective method of teaching social entrepreneurship is learning it in practice and drawing upon good examples of successfully prospering social enterprises. Despite this fact, the vast majority of experts claim that the Polish education system currently plays no significant role in developing the idea of social entrepreneurship. Generally, too little attention is paid to education and shaping a positive attitude towards social economy, social commitment and responsibility. Unfortunately, the Polish education system tends to focus on test scores and the race towards better work, and universities in Poland prepare students by providing general knowledge (Praszkier, Zabłocka-Bursa \& Jozwik, 2014, pp. 24-25). Meanwhile, students should already gain work experience during their studies, and should learn how to establish relationships, participate in building a variety of initiatives, as well as participate in foreign internships. Practical issues are extremely important in education but unfortunately completely neglected at this point. Polish employers have also empirically confirmed this thesis.

Although the Polish education system has introduced a subject called "Entrepreneurship" in secondary and high schools, there are no qualified teachers who could teach it. Therefore, "Entrepreneurship" is usually taught by a teacher of another subject and treated by the students, as well as their parents, as "something unnecessary" or "a subject which can improve your general average grade". The entrepreneurship classes lack any element of practical experience and there is no place for any innovation.

Despite this rather "dark" picture of the role of the educational system in entrepreneurship, there are, however, some positive factors. As an example, the Polish Ministry of Education and Sport has attempted to introduce 25 interesting and innovative projects aimed at instruction of the Entrepreneurship subject by providing numerous grants for the creation of innovative curricula and the pilot implementation of these programs (Praszkier et al., 2014, pp. 24-26). An average student should learn that entrepreneurship is a certain activity, a way of thinking about and treating problems. It is also crucial to sensitise students to the common good, to educate young citizens to develop their social skills and empathy. Furthermore, it is important to present students the idea of community and to familiarise them with the local environment.

However, in order to teach well, a society and its rulers should learn at the beginning what social entrepreneurship really is and apply it to the education system thereafter. Schools, at every level of education, should teach both the theory and practice of social entrepreneurship, and should distinguish and teach what social entrepreneurship, social entrepreneurs and social enterprises are. It requires a whole new generation of initiators and those who can prove it to be possible (Praszkier et al., 2014, p. 26).

The situational analysis revealed that social entrepreneurship is quite slowly developing in Poland. Additional attention is needed in all levels for further improvement of situation. Special attitude should be put on young people as potential for creating social enterprises. Entrepreneurial skills and abilities gained and/ or developed at university might be effective entrepreneurial opportunity created for starting social business. Empirical research seeks to emphasize the importance of such an opportunity. 


\section{Development of Entrepreneurial Skills and Abilities at University as Entrepreneurial Opportunity for Young Lithuanian and Polish Social Entrepreneurs}

When researching the opinion of Lithuanian students on entrepreneurship, the development and improvement of skills and abilities, it becomes obvious that students agree that the teaching process can reinforce the desire and opportunity to become entrepreneurs. According to the opinions of the student target group A (Lithuanian students), the main characteristics such as confidence, risk-taking, courage, creativity, seeking adventure, opportunity creation, leadership, flexibility, originality, innovativeness, spontaneity, communicativeness, capability of decision-making, competitiveness, and persistence might be enforced in the study process. The means to the development of such characteristics could be situation and case study analysis, discussions, teamwork, model creation and decision-making, listening to success stories, as well as various improvisations.

Analysing the results of target group B (Polish students) it should be mentioned that just three of students were attending the course of entrepreneurship. None of them declared of some knowledge about social entrepreneurship. As potential measures for raising young entrepreneurs respondents emphasized the important role of practical examples, features of character such as imagination, adaptiveness were mentioned.

As the most important features of character for entrepreneurial activity, the respondents from target group $C$ indicated: open-mindedness, social ability, management skills, financial and economic knowledge, creativity, responsibility, reliability, leadership, communication skills, languages, self-confidence, risk-taking, positivity, and flexibility. These characteristics could be supported at university by special courses, as well as scientific literature on entrepreneurship.

During the study process, certain entrepreneurial skills and abilities might be introduced and developed as well. According to group A, analytical thinking, adaptiveness to innovation, grounded decision-making, situation and environmental analysis, knowledge of new technologies, organisational skills, communication skills, creativity, responsibility, teamwork, and effective knowledge management might be introduced and/ or developed during tertiary study. For personal features development at university becoming entrepreneur target group B students named knowledge gained at university and teamwork as potential measures.

The most effective measures at university for impetus in creating young entrepreneurs might be: analysis of examples of success; cooperation between the science and business sectors; teamwork; encouragement of competition; generation of ideas; meeting real entrepreneurs; work experience at entrepreneurial enterprises; and innovative projects. In turn, the respondents from group $\mathrm{C}$ indicated management skills, strategic and marketing skills, accounting, organisational skills, communication skills, teamwork, leadership, negotiation skills, analytical thinking, forecasting, networking, flexibility, and encouragement to "free thinking" as entrepreneurial skills and abilities which might be developed during tertiary study.

The most important conditions and/or measures for strengthening entrepreneurial potential at university were given as lectures from current entrepreneurs, practical examples, internships, and project-based activity. As potential measures how to develop entrepreneurial skills and abilities at university target group B students emphasized the 
importance of time management, creativity development and internships provided by university.

In terms of the most important factors for raising and developing young entrepreneurs, respondents from target group A emphasised such factors as a systematic approach to raising entrepreneurs from primary education and high schools, and later at college and university; real stories of successful entrepreneurs in Lithuania; cooperation between business and university;, entrepreneurs' involvement in the study process, and interdisciplinary education. Such measures might help develop social entrepreneurs as well, given the emphasis on social value. Young people are interested in social activity, which might be the first step towards social enterprise creation. Interdisciplinary study programmes have started to be implemented in Lithuania, which may be classed as one of the entrepreneurial opportunities for developing social entrepreneurs. These results are compared in Table 1.

Table 1. Development of entrepreneurial skills and abilities at university

\begin{tabular}{|c|c|c|c|}
\hline Group A & Group B & Group C & \multirow{2}{*}{ Comment } \\
\hline \multicolumn{3}{|c|}{ Measures of personal entrepreneurial features development } & \\
\hline $\begin{array}{l}\text { - situation and case analysis; } \\
\text { - discussions, teamwork; } \\
\text { - model creation and decision } \\
\text { making; listening to success sto- } \\
\text { ries; } \\
\text { - various improvisations. }\end{array}$ & $\begin{array}{l}\text { - teamwork; } \\
\text { - appropriate } \\
\text { knowledge gaining. }\end{array}$ & $\begin{array}{l}\text { - special courses; } \\
\text { - scientific literature } \\
\text { on entrepreneur- } \\
\text { ship. }\end{array}$ & $\begin{array}{l}\text { Lithuanian students, } \\
\text { after completing the } \\
\text { entrepreneurship } \\
\text { course, enumerated } \\
\text { further measures on } \\
\text { how to develop } \\
\text { entrepreneurial } \\
\text { features at universi- } \\
\text { ty. }\end{array}$ \\
\hline \multicolumn{3}{|c|}{ Measures of ways to develop entrepreneurial skill and abilities at university } & \multirow[b]{2}{*}{$\begin{array}{l}\text { Group A and Group } \\
\text { C had a similar } \\
\text { attitude to the } \\
\text { question; it means } \\
\text { that they proposed } \\
\text { measures in the } \\
\text { same manner. } \\
\text { Group B showed the } \\
\text { lack of comprehen- } \\
\text { sion on deeper } \\
\text { suggestions. }\end{array}$} \\
\hline $\begin{array}{l}\text { - analysis of examples of success; } \\
\text { - cooperation between science } \\
\text { and business sectors; } \\
\text { - teamwork; } \\
\text { - encouragement of competition; } \\
\text { - generation of ideas; } \\
\text { - meeting real entrepreneurs; } \\
\text { - work experience at entrepre- } \\
\text { neurial enterprises; } \\
\text { - innovative projects. }\end{array}$ & $\begin{array}{l}\text { - tight schedule with } \\
\text { additional activi- } \\
\text { ties; } \\
\text { - creativity devel- } \\
\text { opment; } \\
\text { - internships. }\end{array}$ & $\begin{array}{l}\text { - lectures from } \\
\text { current entrepre- } \\
\text { neurs; } \\
\text { - practical examples; } \\
\text { - internships; } \\
\text { - project-based } \\
\text { activity. }\end{array}$ & \\
\hline \multicolumn{3}{|c|}{ Measures for raising and developing young entrepreneurs } & \multirow[b]{2}{*}{$\begin{array}{l}\text { Group B and C (non- } \\
\text { students of the } \\
\text { special course) } \\
\text { mostly were focused } \\
\text { on character and } \\
\text { managerial skills } \\
\text { development and } \\
\text { did not demonstrate } \\
\text { a complex view of } \\
\text { the problem. }\end{array}$} \\
\hline $\begin{array}{l}\text { - systematic approach to raising } \\
\text { entrepreneurs from primary edu- } \\
\text { cation and high schools, and later } \\
\text { at college and university; } \\
\text { - real stories of successful entre- } \\
\text { preneurs in Lithuania; } \\
\text { - cooperation between business } \\
\text { and university; } \\
\text { - entrepreneurs' involvement in } \\
\text { the study process; } \\
\text { - interdisciplinary education. }\end{array}$ & $\begin{array}{l}\text { - involving real } \\
\text { entrepreneurs in } \\
\text { education process; } \\
\text { - strong character } \\
\text { development; } \\
\text { - practice; } \\
\text { - imagination; } \\
\text { - adaptiveness. }\end{array}$ & $\begin{array}{l}\text { - managerial skills; } \\
\text { - simulations; } \\
\text { - traineeships; } \\
\text { - good ideas; } \\
\text { - planning; } \\
\text { - teamwork; } \\
\text { - decision making; - } \\
\text { critical thinking. }\end{array}$ & \\
\hline
\end{tabular}

Source: own study. 
The students' research disclosed one of the most significant aspects pertaining to the role of education in the development of social entrepreneurs. Students, being young people and potential young entrepreneurs, strongly believe that entrepreneurial skills and abilities might be strengthened or even acquired at university and could be leading to entrepreneurial possibilities. They are interested in finding out more about social entrepreneurship and its peculiarities. It reaffirms the main conclusion that education institutions and the study process might be an appropriate place and an effective instrument for raising and enhancing young social entrepreneurs in Lithuania. The completed research implies future perspectives for the research of some task groups at Polish universities, where students have already been studying course of Entrepreneurship. It might be considered that students who are more experienced internationally, studying at different universities, have different experience. In the same time target group $\mathrm{C}$ students exposed weak knowledge in analysed question.

\section{DISCUSSION}

The fulfilled analysis and research allowed discovering several important aspects associated with social entrepreneurship in Poland and Lithuania. Students believe that entrepreneurial skills and abilities might be strengthened or even acquired at university. Therefore, one may say that education system plays an important role in shaping and developing social entrepreneurship in both countries. When coming to the details, however, one could see unless there are both similarities as well as differences in this aspect. For example, Polish respondents stressed that despite the fact there are 'Entrepreneurship" topics at the secondary schools, they are generally taught by unqualified teachers. In contrast to this fact, the Lithuanian respondents did not raise this aspect. In turn, both group of respondents generally agree as to the features the potential entrepreneur should have.

Secondly, the results achieved suggest that the education system is a strong tool for social entrepreneurship development providing entrepreneurial opportunities for young entrepreneurs. It requires, however, enforcement and flexibility, a review of study programmes, and especially a constant support from business and society. Lack of these elements will cause that the potential of this will not be fully utilized or even lost.

Thirdly, one seems to us that there is a difference in development level of social entrepreneurship in Lithuania and Poland. Lithuania is a little more advanced in this regard. However, the existence of various entrepreneurial opportunities, especially education at the university, caused that social entrepreneurship has been increasingly attracting interest in Poland and starting to develop very quickly. One of the reason may be the size of the countries analysed: in case of the smaller countries, it is always easier and faster to implement certain solutions. Despite these differences, overall support is needed at economic, political, legal, and social levels for the creation of social enterprises and, especially, for attracting young people to them. It relates to both countries as, based on the experience of Western countries, one may state that there is a big potential in social entrepreneurship.

Fourthly, empirical research based on Lithuanian and Polish students' perception of the development of entrepreneurial skills and abilities at university as entrepreneurial opportunity demonstrate several very positive tendencies and trends. For example, in- 
volvement in entrepreneurship attracts more and more interest, and the appropriate skills and abilities can be gained or/and developed at university during the study process. On the other hand, this process still requires further work and analyses, e.g. case studies, presentation of achievements of real entrepreneurs, participation in the business projects etc.

\section{CONCLUSIONS}

The literature review undertaken in our paper allows to emphasise the importance of scientific problems raised in the article in the framework of the subject analysed - social entrepreneurship. It is something of a new phenomenon in Poland and Lithuania from both perspectives - research and practice. The EU initiatives strongly support social enterprises and force countries to take the appropriate actions in developing social entrepreneurship while exploiting the entrepreneurial opportunities, which exist or can be created. Theoretical research reveals that education can be regarded as the entrepreneurial opportunity, which can be exploited by young people in terms of gaining entrepreneurial skills and abilities at university.

Empirical research allows concluding that despite fragmental initiatives, the development of social entrepreneurship remains slow in Poland. The role of the education system is not sufficient effectively assist young people in gaining the appropriate entrepreneurial skills and abilities. A similar situation remains in Lithuania in terms of the education system and teaching entrepreneurship - although some initiatives are positive, a lack of any form of systemic approach still exists. Students are keen on learning entrepreneurial skills and abilities but they state that methods and measures could be improved for a more effective study process in the field of entrepreneurship, especially social. Empirical research in Lithuania revealed that education is a powerful tool for inspiring and motivating young people to become the creators of social enterprises. As empirical research remains just pilotage these assumptions could be applied just in similar situations arising applying research instrument. The more respondents should be involved if gaining more explicit results in different Polish and Lithuanian universities, especially focusing on concrete entrepreneurial skill and abilities research, which is important for social entrepreneurship.

In conclusion, it should be mentioned that both countries require better-integrated and well-managed actions in the development of social entrepreneurship and encouraging young people to become creators of social enterprises. Empirical research results provide opportunity to develop study programmes at university based on entrepreneurial skills and abilities development as exposing entrepreneurial opportunity. Empirical research limitations are mostly based on limited target groups. Future research could be based on quantitative method and different countries; especially EU, research as well as research instrument could be different for listeners of specialised Entrepreneurship course and non-listeners of such courses. 


\section{REFERENCES}

Aldrich, H., \& Martinez, M. (2007). Many are Called, but Few are Chosen: An Evolutionary Perspective for the Study of Entrepreneurship. In A. Cuervo, D. Ribeiro, \& S. Roiq (Eds.), Entrepreneurship: Concepts, Theory and Perspective (pp. 293-311). Berlin: Springer.

Ardichvili, A., Cardozo, R., \& Sourav, R. (2003). A theory of entrepreneurial opportunity identification and development. Journal of business Venturing, 18, 105-123.

Audretsch, D.B., \& Acs, Z.J. (2003). Handbook of entrepreneurship research: an interdisciplinary survey and introduction. New York: Springer.

Austen-Tynda, A. (2008). Social entrepreneurship in Poland: implications for public management. Management, 12(2), 199-212.

Casson, M.C. (1982). The Entrepreneur: An Economic Theory. Oxford: Martin Robertson.

Casson, M.C., \& Wadeson, N. (2007). The Discovery of Opportunities: Extending the Economic Theory of the Entrepreneur. Small Business Economics, 28(4), 285-300.

Choi, Y.R., \& Shepherd, D.A. (2004). Entrepreneurs' Decision to Exploit Opportunities. Journal of Management, 30(3), 377-395.

Choi, Y.R., Levesque, M., \& Shepherd, D.A. (2008). When should entrepreneurs expedite or delay opportunity exploitation? Journal of Business Venturing, 23(3), 333-355.

Ciepielewska-Kowalik, A. (2013). Trends and challenges for social enterprises in Poland. A new model of social investments and social cohesion. Paper presented at 4th EMES International Research Conference on Social Enterprise "If Not For Profit, For What? And How?", July 1-4, 2013, Liege: University of Liege.

Ciepielewska-Kowalik, A. (2015). Socio-economic, political and historical context of the emergence of the Social Economy in childcare in Poland (1989-2014). Looking for social inclusion and cohesion enhancement. Retrieved on June 30, 2016 from http://www.ciriecportugal.org/ uploads/9/6/4/3/9643491/ciriec2015_0259_paper.pdf

Ciepielewska-Kowalik, A., Pieliński, B., Starnawska, M., \& Szymańska, A. (2015). Social enterprise in Poland: institutional and historical context. ICSEM Working Papers, No. 11, Liege: The International Comparative Social Enterprise Models (ICSEM) Project.

Companys, Y.E., \& McMullen, J.S. (2007). Strategic Entrepreneurs at Work: The Nature, Discovery, and Exploitation of Entrepreneurial Opportunities. Small Business Economics, 28(4).

Dahlqvist, J., \& Wiklund, J. (2012). Measuring the market newness of new ventures. Journal of Business Venturing, 27, 185-196.

Davidsson, P. (2008). The entrepreneurship research challenge. Cheltenham: Edward Elgar.

Davidsson, P., \& Honig, B. (2003). The role of social human capital among nascent entrepreneurs. Journal of Business Venturing, 18(3), 301-331.

De Jong, J.P.J. (2009). The decision to innovate: antecedents of opportunity exploitation in high tech small firms. Scales: Zoetermeer.

Dimov, D. (2007). Beyond the single-person, single-insight attribution in understanding entrepreneurial opportunities. Entrepreneurship Theory and Practice, 31(5), 713-731. 
Doherty, B., Haugh, H., \& Lyon, F. (2014). Social Enterprises as Hybrid Organizations: A Review and Research Agenda. International Journal of Management Reviews, 16(4), 417-436.

Drayton, W. (2002). The citizen sector: becoming as entrepreneurial and competitive as business. California Management Review, 44(3), 120-132.

Dutta, D.K., \& Crossan, M.M. (2005). The Nature of Entrepreneurial Opportunities: Understanding the Process Using the 4 I Organizational Learning Framework. Entrepreneurship Theory and Practice, 29(4), 425-449.

Eckhardt, J.T., \& Shane, S.A. (2003). Opportunities and Entrepreneurship. Journal of Management, 29(3), 333-349.

European Commission (2014). A map of social enterprises and their eco-systems in Europe. Country Report: Poland. Brussels: European Commission.

Fuentes, M., Arroyo, M.R., \& Perez, V.F. (2010). Prior Knowledge and Social Networks in the Exploitation of Entrepreneurial Opportunities. International Entrepreneurship Journal, 6, 481-501.

Greblikaite, J., Sroka, W., \& Grants, J. (2015). Development of social entrepreneurship in European Union: policy and situation of Lithuania and Poland. Transformations in Business \& Economics, 14(2B) (35B), 376-396.

Hausner, J. (Ed.) (2008). Przedsiębiorstwa społeczne w Polsce. Teoria i praktyka. Kraków: Uniwersytet Ekonomiczny w Krakowie, Małopolska Szkoła Administracji Publicznej.

Hayek, F. (1945). The use of knowledge in society. American Economic Review, 35(4), 519-530.

Herbst, J. (2008). Polski trzeci sektor w świetle teorii przedsiębiorstwa społecznego. In J. Dąbrowska (red.), Od trzeciego sektora do przedsiębiorczości społecznej - wyniki badań ekonomii spotecznej w Polsce (pp. 125-142). Warszawa: Stowarzyszenie Klon/Jawor.

Holcombe, R.G. (2003). The origins of entrepreneurial opportunities. The Review of Austrian Economics, 16(1), 25-43.

Jesensky, D. (2013). Creating entrepreneurial opportunities: Interpretative Research about Role of POP Advertising Displays in Customer Purchase Decision Making. Jyvaskyla: University Library of Jyvaskyla.

Korosec, R., \& Berman, E. (2006). Municipal support for social entrepreneurship. Public Administration Review, 66(3), 446-462.

Kożuch, A., \& Žukovskis, J. (2014). Effective managing of social co-operatives as a form of social enterprise: the case of Poland. International Journal of Contemporary Management, 134(4), 83-96.

Kurleto, M. (2013). Possibility of using in Poland contemporary solutions concerning philanthropy and social entrepreneurship adopted in the U.S. Global Management Journal, 5(1-2), 28-35.

Kusa, R. (2012). Social entrepreneurship in Poland. A preliminary comparison of research approaches. 1st Virtual International Conference on Advanced Research in Scientific Fields (ARSA2012), 3-7 December, 94-97.

Leś, E. (2004). Co-operatives in Poland: from state-controlled institutions to new trends in cooperative development. In C. Borzaga, \& R. Spear (Eds.), Trends and challenges for cooperatives and social enterprises in developed and transition countries (pp. 185-196). Trento: Edizioni 31. 
Leś, E., Ciepielewska-Kowalik, A. (2014). Social economy and social enterprises in Poland: trends, challenges and obstacles. Paper presented at 54th ERSA Congress, St. Petersburg, August 2629.

Mair, J., \& Marti, I. (2006). Social entrepreneurship research: A source of explanation, prediction, and delight. Journal of World Business, 41, 36-44.

Peredo, M., \& McLean, M. (2006). Social entrepreneurship: a critical review of the concept. Journal of World Business, 41, 56-65.

Plummer, L.A., Haynie, J.M., Godesiabois, J. (2007). An Essay on the Origins of Entrepreneurial opportunity. Small Business Economics, 28, 363-379.

Praszkier, R., Zabłocka-Bursa, A., \& Jozwik, E. (2014). Social enterprise, social innovation and social entrepreneurship in Poland. EFESEIIS National Report, Warsaw: University of Warsaw.

Roure, C.L., González, N., Nieto, M., García, C., \& Solís, V. (2007). Influencia de la existencia y el descubrimiento de oportunidades sobre la actividad emprendedora. Revista de Empresa: La Fuente de Ideas del Ejecutivo, 20, 66-77.

Schumpeter, J. (1934). Theory of Economic Development. Cambridge, MA: Harvard University Press.

Shane, S. (2000). Prior knowledge and the discovery of entrepreneurial opportunities. Organization Science, 11(4), 448-469.

Shane, S. (2003). A general theory of entrepreneurship: the individual-opportunity nexus. Cheltenham, UK: Edward Elgar.

Shane, S., \& Venkatarman, S. (2000). The promise of entrepreneurship as a field of research. Academy of Management Review, 25(1), 217-226.

Shepherd, D.A., \& DeTienne, D.R. (2005). Prior knowledge, potential financial reward, and opportunity identification. Entrepreneurship Theory and Practice, 29, 91-112.

Short, J.C., Ketchen, D.J., Shook, C.L., \& Ireland, R.D. (2010). The Concept of "Opportunity" in Entrepreneurship Research: Past Accomplishments and Future Challenges. Journal of Management, 36(40), 40-62.

Smith, B.R., Matthews, C.H., \& Schenkel, M.T. (2009). Differences in entrepreneurial opportunities: the role of tacitness and codification in opportunity identification. Journal of Small Business Management, 47(1), 38-57.

Soderqvist, A. (2011). Opportunity exploration and exploitation in international new ventures: a study of relationships' involvement in early entrepreneurial and internationalization events. Helsinki: Edita Prima.

Starnawska, M. (2011). Resourcing in social enterprise - content analysis of 'good practices' profiled in 'Atlas of social economy' in Poland. Retrieved on April 30, 2016 from http://emes.net/content/uploads/publications/resourcing-in-social-enterprise-content-analy sis-of-good-practices-profiled-in-atlas-of-social-economy-in-poland/5ESCP-02-Resourcing_in_ social_enterprise_content_analysi s_Marzena_Starnawska.pdf

Thompson, T.L. (2002). The world of the social entrepreneur. International Journal of Public Sector Management, 15(5), 412-431.

Ucbasaran, D., Westhead, P., \& Wright, M. (2009). The extent and nature of opportunity identification by experienced entrepreneurs. Journal of Business Venturing, 25, 99-115. 
Von Hippel, E. (1994). 'Sticky information' and the locus of problem solving: implications for innovation. Management Science, 40(4), 429-439.

Zahra, S.A., Korri, J.S., \& Yu, J. (2005). Cognition and international entrepreneurship: implications for research on international opportunity recognition and exploitation. International Business Review, 14(2), 129-146.

Zahra, S.A., Gedajlovic, E., Neubam, D.O., \& Shulman, J.M. (2009). A typology of social entrepreneurs. Motives, search processes and ethical challenges. Journal of Business Venturing, 24, 519-532. 


\section{Authors}

All authors have worked preparing all parts of article. Special input about Polish situation analysis was made by W. Sroka. Empirical research of students' entrepreneurial skills and abilities was fulfilled with additional efforts of J. Greblikaite, while N. Gerulaitiene was analysing the concept of entrepreneurial opportunity in the context of social entrepreneurship.

\section{Jolita Greblikaite}

Associate professor at Aleksandras Stulginskis University and Marijampole College, (Lithuania). The author of more than 30 scientific papers (including those published in ISI journals) as well as chapters in monographs and scientific studies in Lithuania and abroad (Ukraine, USA, and Germany). She is also a member of several editorial boards in scientific journals and organising committees of international scientific conferences. She has taught in Germany, Finland, the Czech Republic, and Cyprus, staging at Finland and Poland. She focuses her scientific research in the fields of entrepreneurship, especially social, social enterprises, young entrepreneurs, as well as cross-cultural management and business ethics issues.

Correspondence to: Doc. Dr. Jolita Greblikaite; Aleksandras Stulginskis University; Institute of Business and Rural Development Management; Universiteto str. 10-417; Akademija, Kauno raj., Lithuania; e-mail: jolita19@gmail.com

\section{Włodzimierz Sroka}

Associate Professor at the University of Dąbrowa Górnicza (Poland), and simultaneously is the president of a medium-size engineering company. He has earned Ph.D., M.Sc. and B.Sc. degrees in Management and Marketing from the Karol Adamiecki University of Economics in Katowice, as well as a D.Sc. degree (habilitation) from the University of Žilina (Slovakia). He has authored several monographs published by Springer Verlag and Shaker Verlag. He special-ises in theoretical and practical issues relating to management and strategic management.

Correspondence to: Dr hab. Włodzimierz Sroka; University of Dąbrowa Górnicza; Department of Management; ul. Cieplaka 1c; 41-300 Dąbrowa Górnicza, Poland; e-mail: wsroka@wsb.edu.pl

\section{Neringa Gerulaitiene}

PhD student at the School of Economics and Business at Kaunas University of Technology (Lithuania). She gained a Master's degree in International Business Management and a Bachelor's degree in Public Administration. Her main research interests are in entrepreneurship, especially entrepreneurial opportunity exploitation.

Correspondence to: Neringa Gerulaitiene; Kaunas University of Technology; Department of Strategic Management; Gedimino str. 50; Kaunas LT-44239, Lithuania; e-mail: neringa.puskoriute@gmail.com

\section{Copyright and License}

This article is published under the terms of the Creative Commons Attribution - NonCommercial - NoDerivs (CC BY-NC-ND 3.0) License http://creativecommons.org/licenses/by-nc-nd/3.0/ 